\title{
THE S'TRAWBERRY ROOT LOUSE (APHIS FORBESI N. S.)
}

\author{
BY ClARENCE MOORES WEED, COLUMBUS, OHIO.
} [Partial reprint from Bull. Ohio agricultural experiment station, September 1889, v. 2, no. 6. p.
I 48-150.]

During the latter part of August Mr. S. R. Kramer, of Gahanna, Franklin county, Ohio, brought me specimens of a small louse infesting the roots of strawberry plants, which he reported to have ruined a plantation some two and a half acres in extent. An examination of the plants upon the station grounds showed that a large proportion of them were also infested by the same insect; and on inquiring of prominent horticulturists recently assembled at the state fair, I found that many of them were only too well acquainted with the pest, and that it is quite generally distributed over the state.

The insect proved to be a species of Aphis. to which attention was first called by Professor S. A. Forbes in the Thirteenth report of the state entomologist of Illinois (p. 102-103).

On the station plants the lice occur both upon the roots and lower portions of the crowns. In both situations they are carefully attended by the small brown ant (Lasius alienus) which mines about the roots, upon which it probably places the lice, and carries them away in its jaws upon the approach of danger - treating them in fact exactly as it treats the corn root louse (Aphis maidis) in corn fields. From the discovery of the deposition of the plant-lice eggs about the strawberry roots recorded by Professor Forbes, I surmise that the ants take care of them through the winter, in the same way that they have been found, by the author just mentioned, (Amer. nat., v. 21 , p. 579) to care for the eggs of the corn root louse.

Mr. Kramer informs me that he first found these lice upon his plants about the middle of July, when they were very abundant.

A great many of the lice on the crowns and roots were infested with hymenopterous parasites.

\section{DESCRIPTION.}

Although Professor Forbes published an accurate description and figure of this strawberry root louse, he did not give it a specific name, and consequently I have proposed that it be named

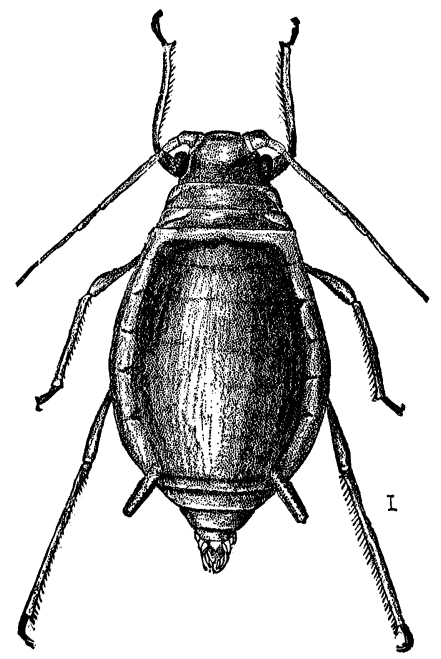

in honor of its discoverer, and called forbesi. The form now present on the roots is shown magnified at Fig. I, and may be described as follows : 
APterous VIVIPAROUS FEMALE.

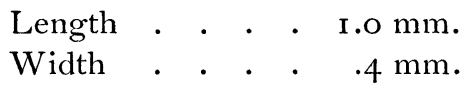

Body, small, ovate. Color, dark bluish-green : head, yellowish or greenish ; antennae, yellowish-brown toward base, darker apically; eyes, reddish ; legs, yellowish or yellowish-brown, ex-

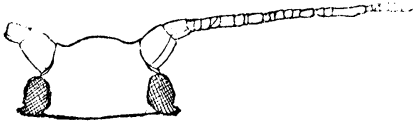

cept the tibio-femoral articulations and tarsi, which are dusky; cornicles, yellowish or yellowish-brown at base, darker apically; cauda varying from bluish-green to yellowish or yellowishbrown. Antennae about half as long as body, roughened, as shown at Fig. 2, six-jointed ${ }^{1}$; joints I and II sub-equal in length, I being slightly broader than II ; III long, slightly longer than IV plus $\mathrm{V}$, but a little shorter than VI; IV about half as long as III; V short, two-thirds as long as IV; VI longest. Cornicles long, slightly tapering, flanged at tip. Cauda prominent, flattened, with a number of curved hairs along the margin. Prothorax with a blunt tubercle on each side.

Described from many living specimens taken on roots of strawberry plants, 7 Septernber, i 889 .

\footnotetext{
1 Although I agree with Forbes and Lichtenstein that what is here called the sixth joint of the antenna is really the prolongation of the fifth, I follow the general practice of calling it distinct for sake of brevity and convenience.
}

\section{CLASSIFIED LIST OF FOOD PLANTS OF AMERICAN BUTTER- FLIES, DRAWN FROM SCUDDER'S "BUT'TERFLIES OF THE EASTERN UNITED S'TATES."}

[Names followed by an * indicate the plants for which the species concerned have a decided preference. Those enclosed in parentheses are exceptional or doubtful.]

Ceners semidea. Cyperaceae, Carex vulgaris var. hyperborea.

Oeneis Jutra. Cyperaceae, Carex oligo. sperma ;* Gramineae; (Funcaceae, Juncus articulatus).

Cercyonis alope. Gramineae.

Cercyonis nephele. Gramineae.

Enodia portlandia. (Urticaceae, Celtis occidentalis); Gramineae.*

Satyrodes eurydice. Cyperaceae, Scirpus eriophorum, Carex bromoides; Gramineae.

Neonympha phocion. Gramineae, Panicum sanguinale, Dactolytenium aegyptiacum.
Cissia eurytus. Leguminosae, Trifo. lium; Xyridaceae, Xyris torta ; Gramineae.*

Chlorippe clyton. Rosaceae, Prunus; Aristolochiaceae, Aristolochia; Urticaceae, Celtis occidentalis.*

Basilarchia archippus. Rosaceae, Prunus, Pirus, Chrysobalanus oblongifolius; Salicaceae,* Salix nigra, S. livida var. occidentalis, S. sericea, Populus balsamifera var. candicans, P. tremuloides, P. monilifera, P. dilatata.

Basilarchia astyanax. Rosaceae, ${ }^{*}$ Pru. nus, Pirus, Crataegus, Cydonia; Grossulaceae, Ribes; Ericaceae, Vaccinium stami- 

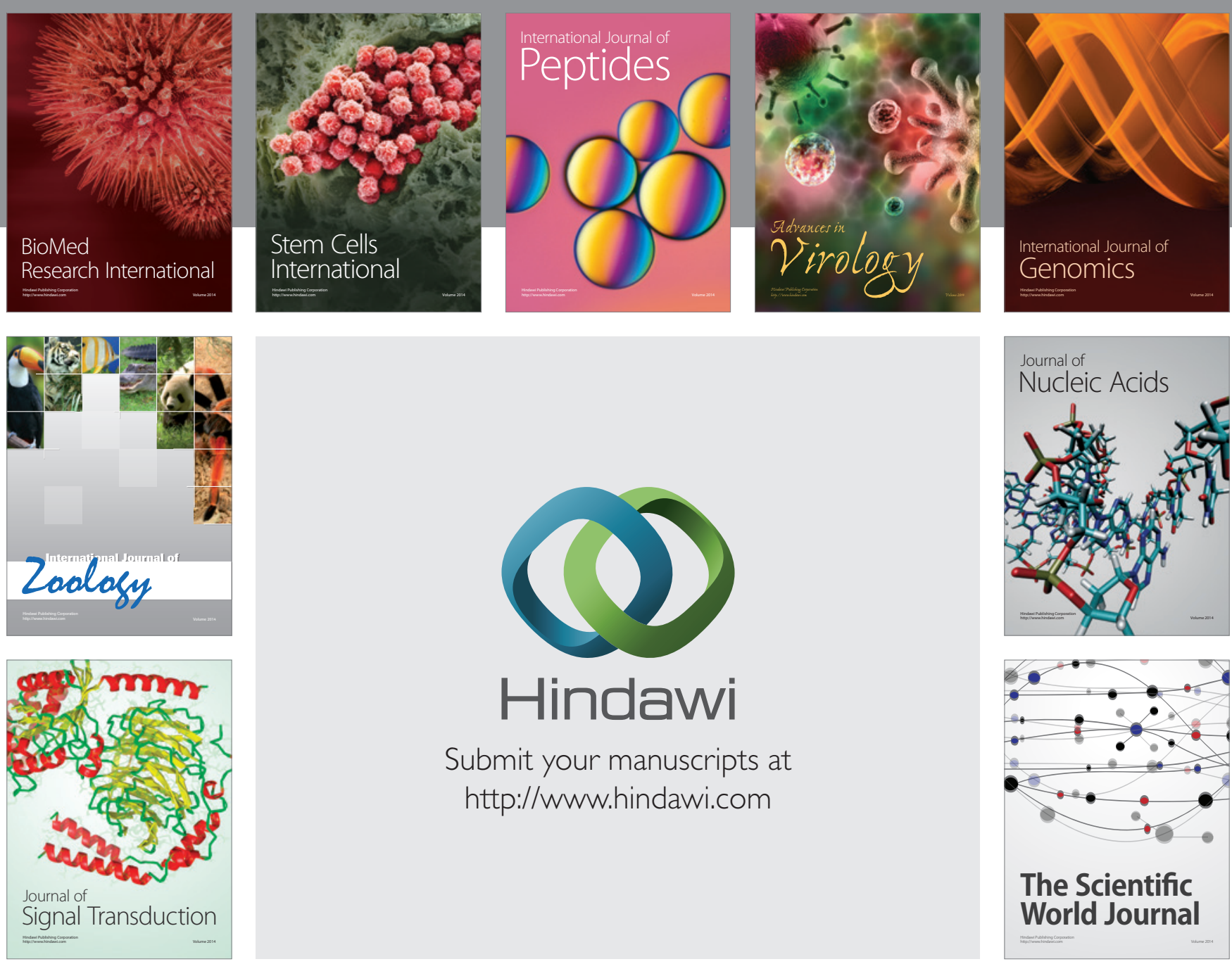

Submit your manuscripts at

http://www.hindawi.com
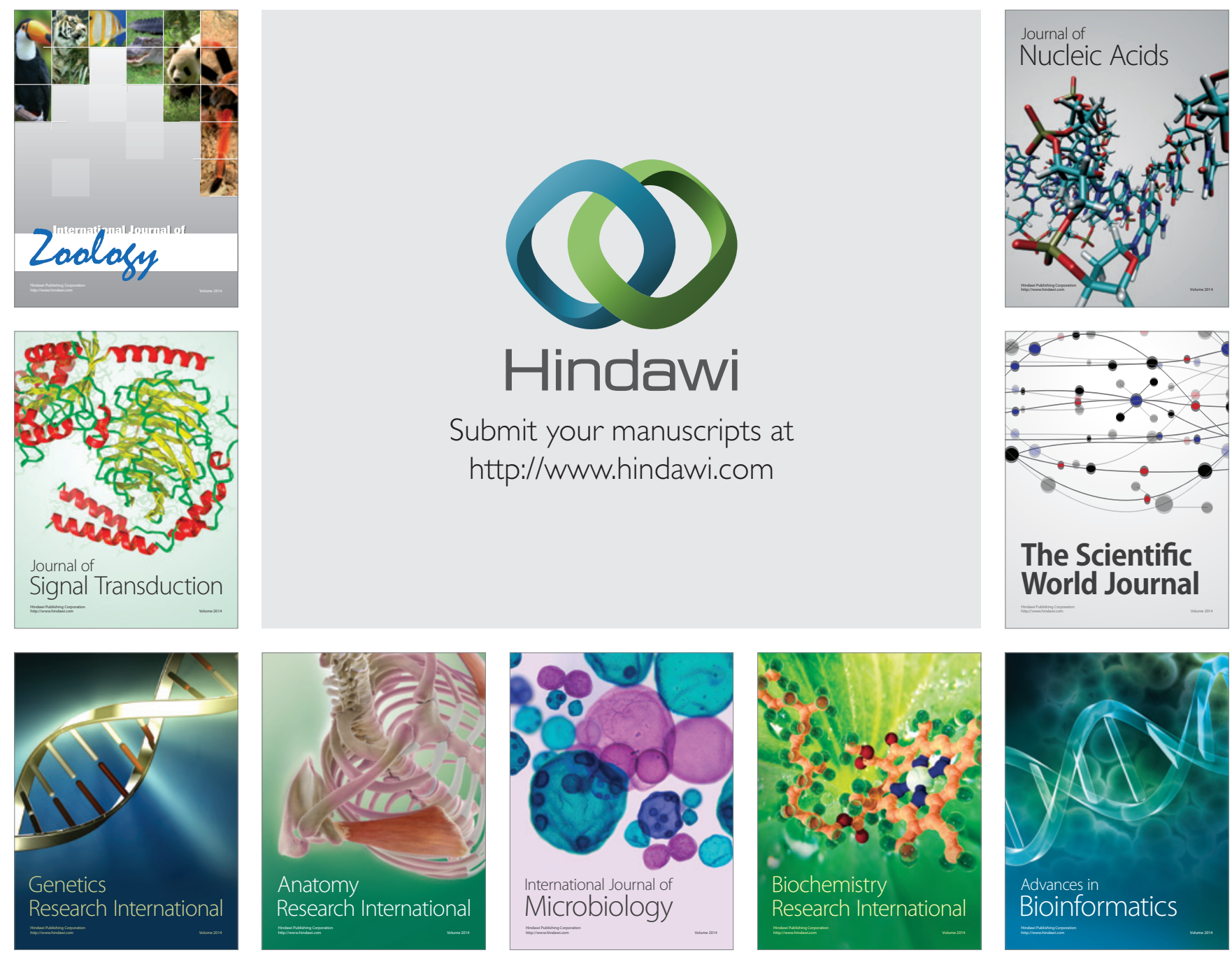

The Scientific World Journal
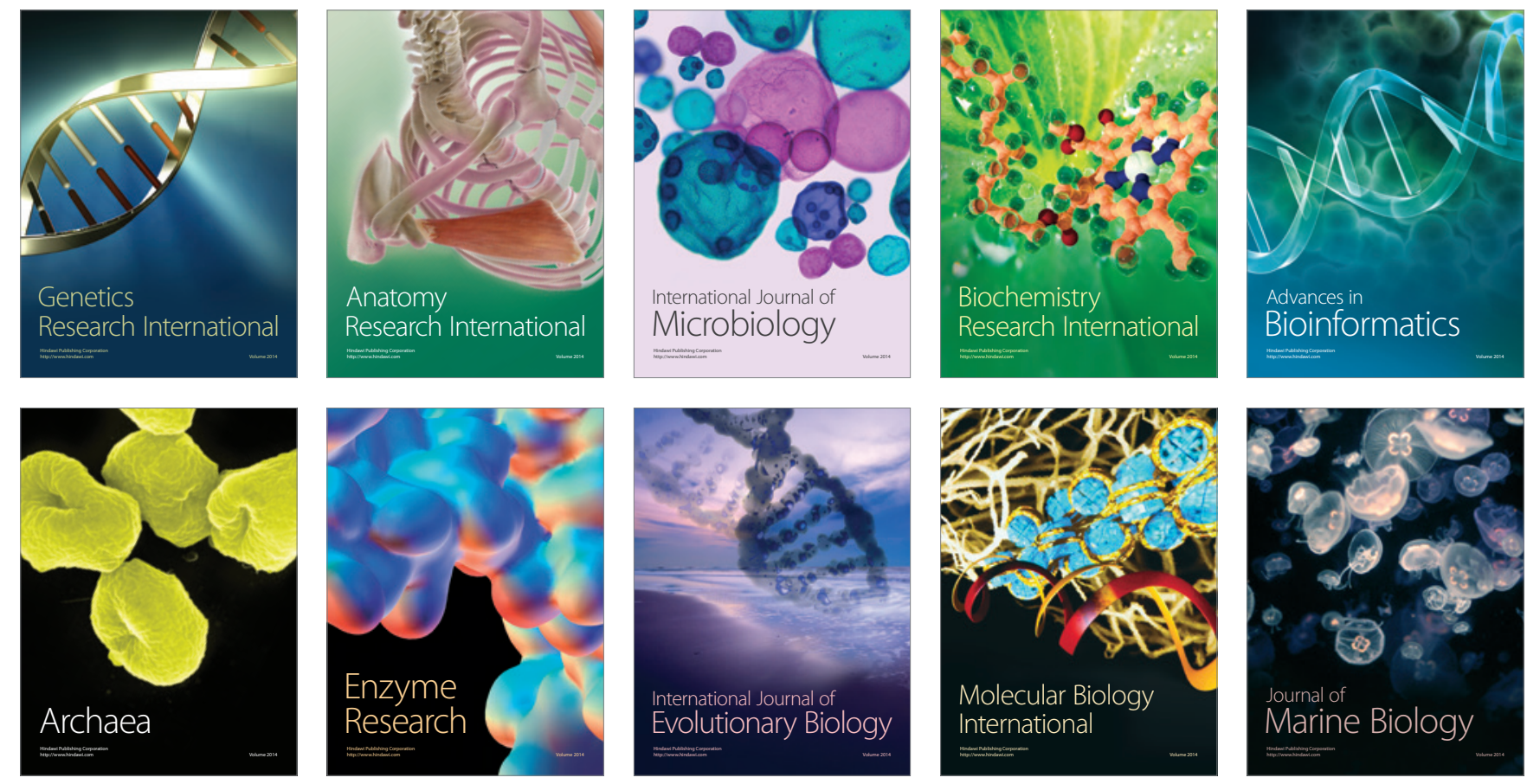